\title{
Scale Development and Operationalization of Social Responsibility Constructs: An ISO 26000 Context
}

\author{
Pui-Sze Chow \\ Centennial College, Wah Lam Path, Pokfulam, Hong Kong \\ E-mail: linda.psl.chow@centennialcollege.hku.hk
}

Ailie K.Y. Tang

Centennial College, Wah Lam Path, Pokfulam, Hong Kong

E-mail: ailie.tang@centennialcollege.hku.hk

\author{
Amy C.Y. Yip (Corresponding author) \\ Centennial College, Wah Lam Path, Pokfulam, Hong Kong \\ E-mail: amy.yip@centennialcollege.hku.hk
}

Received: May 16, 2016 Accepted: May 30, 2016

doi:10.5296/ber.v6i2.9865 URL: http://dx.doi.org/10.5296/ber.v6i2.9865

\begin{abstract}
ISO 26000 is one of those prevailing guidelines on social responsibility adopted by practitioners. Despite its growing embracement, the dimensions of ISO 26000 have not been empirically operationalized. The lack of validated scales limits its compatibility in real-life practices as well as academic research on the standard. Adopting quantitative and qualitative methodology, the multidimensional scale of ISO 26000 is first operationalized through a questionnaire survey with 286 organizations in Hong Kong. The measurement items are then triangulated with industrial evidence garnered from in-depth interviews with seven organizations comprising two listed companies, two private companies, and three non-governmental organizations with operations in Hong Kong, Macau, Mainland China, Asia and the Middle East. Our measurement scale contributes to future studies of ISO 26000 in the corporate social responsibility literature. The validated scale will also be a handy guide for aligning social responsibility with the practical context and strategic implantation.
\end{abstract}

Keywords: Corporate social responsibility (CSR), ISO 26000, Scale development and 
validation, CSR measurement, Mixed quantitative and qualitative methodology

\section{Introduction}

Corporate social responsibility (hereafter called CSR) sits at the top of the agenda for many organizations in light of globalization and demands from stakeholders. Some fundamental issues concerning CSR include stakeholder management, sustainability assessment and social responsibility standardization. Subsequently, a number of international standards have been introduced to advocate and guide CSR implementation and reporting by organizations. Some common international standards to date include: G4 Sustainability Reporting Guidelines (GRI, 2013), UN Global Compact framework (United Nation Global Compact, 2014), and ISO 26000 (ISO, 2010).

Developed by the International Organization for Standardization (ISO for short), an independent and non-government organization, ISO 26000 aims to provide guidelines to organizations of all sizes and natures on how to operationalize social responsibility from a multi-stakeholder perspective. In particular, the standard recognizes seven principles of social responsibility, namely: accountability, transparency, ethical behaviour, respect for stakeholder interests, respect for the rule of law, and respect for international norms of behaviour. From the operational dimension, the standard identifies seven core subjects that all organizations should address when undertaking their social responsibilities. These seven core subjects include: (a) organizational governance, (b) human rights, (c) labour practices, (d) the environment, (e) fair operating practices, (f) consumer issues, and (g) community involvement and development (Figure 1). A list of specific issues for individual core subjects is highlighted. The list provides guidance on how an organization should engage and take into consideration of its various stakeholders, such as employees, customers, suppliers, local community and the environment.

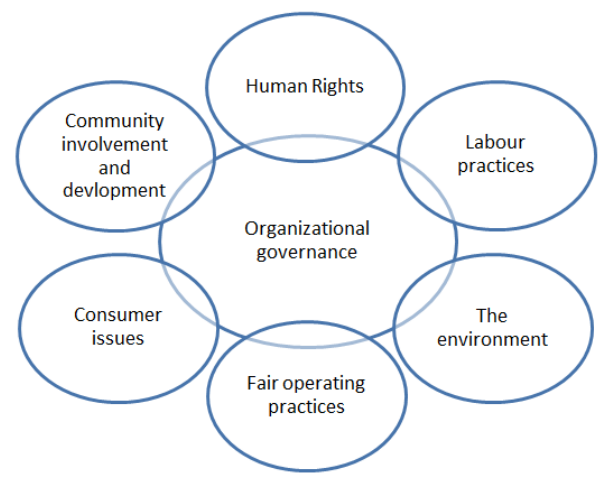

Figure 1 . The seven core subjects addressed by ISO 26000 guidance

Adapted from: ISO (n.d.)

Although there are a growing number of organizations that apply ISO 26000 to structure their CSR initiatives, the dimensions and constructs under ISO 26000 have not yet been empirically validated. The potential conceptual overlap or incomprehension in the dimensions may distort how the standard could be used in practice. It is thus of utmost 
importance to operationalize and validate the measurement scales of ISO 26000. This study, therefore, aims to develop and validate the measurement scale of ISO 26000 constructs on social responsibility with a mixed quantitative and qualitative methodology. A measurement scale is first developed and complied with reference to the ISO 26000 standard. A questionnaire survey and statistical analysis is then conducted to meticulously validate the measurement scale. Afterwards, in-depth interviews with organizations of different natures are held for conducting qualitative analysis to triangulate the validity of the measurement scale.

This paper contributes to the literature in a number of ways: (1) to the best of our knowledge, this paper is the first that operationalizes the construct of CSR with reference to ISO 26000. Different from other studies that also develop scales for CSR measurement (e.g., Turker, 2009; Shafiq, Klassen \& Johnson, 2014), our scale is constructed under the context of ISO 26000, which enables assessment by industrials who are familiar with the guidelines in their daily operations. (2) The applicability of the proposed measurement scales is demonstrated with industrial evidence that is collated from a series of interviews with organizations of various natures. (3) Capturing multiple dimensions of CSR practices, it is believed that the measurement scale developed in this paper could expedite researchers in their future studies related to CSR.

This paper is organized as follows. Section 2 reviews the CSR literature related to ISO 26000. Section 3 portrays the methodology and scale validation procedures. Section 4 summarizes interview results with various organizations of different natures regarding their CSR practices under the context of the proposed measurement scale. Section 5 discusses the above findings and provides managerial insights. Finally, Section 6 addresses limitations of this study and suggests future research directions.

\section{Literature Review}

The importance of stakeholder concerns and engagement (Manetti, 2011) are emphasized in many international CSR-related standards including ISO 26000. Stakeholder theory (Freeman, 1984) is one of the important genres of principles in CSR. Its principles and related literature are reviewed as follows.

Stakeholder theory highlights the normative aspect of management and emphasizes the moral behavior of the firm (Jones, Wicks, \& Freeman, 2002). It addresses two issues of business, namely: the purpose of the firm, and the management's obligation to different stakeholders (Freeman, 1994; Donaldson \& Preston, 1995). The term stakeholder first appeared under the management context in an internal memorandum of the Stanford Research Institute in 1963 to refer to "those groups without whose support the organization would cease to exist" (Freeman \& Reed, 1983). Nowadays, the definition by Freeman (1984, p. 25) as "any group or individual who can affect or is affected by the achievement of the firm's objectives" has been the most commonly adopted version. Accordingly, the stakeholder perspective of business suggests that the management should fulfill and align the interests amongst diverse stakeholders so as to create value and avoid risk (Post, Preston, \& Sachs, 2002). Stakeholder theory has spurred a number of debates about its foundation and limitations in the academia 
(Laplume, Sonpar, \& Litz, 2008; Parmar, et al., 2010); however, it remains to be a popular research topic across a wide variety of disciplines. For instance, in the strategic management domain, Ackermann and Eden (2011) examine real-world applications of the concepts of stakeholder management in 16 organizations under a 15-year time period. The authors propose techniques that help top management to structure the perspectives of the key stakeholders and to decide on the approach of strategic management more quickly. Frow and Payne (2011) relate stakeholder theory with value propositions in a marketing system. The authors develop a five-step process to identify key stakeholders and explore how value co-creation can be achieved amongst multiple stakeholders. De Brucker, Macharis and Verbeke (2013) investigate the effectiveness of multi-criteria analysis to project evaluations for sustainable development. The authors demonstrate how the stakeholder orientation of the analysis can facilitate decision making and improve governance of the projects.

ISO 26000 adopts a multi-stakeholder approach and is one the most commonly adopted references related to CSR. According to the survey conducted by ISO 26000 Post Publication Organization in 2012, the standard has been adopted as a national standard by at least 60 countries and is available in 22 languages (Lazarte, 10 January 2013). Despite its increasing popularity amongst practitioners since its launch in 2010, ISO 26000 is seldom discussed in the literature. Some of these studies are reviewed as follows. Castka and Balzarova (2007) examine the guideline during its development stage from the quality management perspective and suggest initiatives (such as incorporation of corporate governance, third-party certification, and strengthened internal audit procedures) that could enhance deployment of the guidance and in turn CSR. Later, Castka and Balzarova (2008) propose that ISO 26000 could eventually serve as a benchmark for CSR and explain the reasons and types of companies and supply chains that might pioneer in adopting the guidelines. By contrast, Schwartz and Tilling (2009) question the standardization approach of sustainability development might "decouple complex CSR issues". Based on an extensive literature review and making reference to four hypothetical companies, Hahn (2013) discusses the potential contribution of ISO 26000 to different stages of strategic management processes. Barnes and Croker (2013) empirically examine the perceived importance of ISO 26000 core subjects to the Hong Kong construction industry and conclude that large construction contractors are mostly concerned with the environment and labour issue (in particular health and safety in the workplace) whereas small-and-medium-enterprises (SMEs) find many principles in ISO 26000 irrelevant to their operations. Recently, Habidin, Fuzi, Desa, Hibadullah and Zamiri (2012) and Fuzi, Habidin, Desa, Zamri and Hibadullah (2013) respectively explore the relationship between CSR practices and implementation efforts of ISO 26000 in Malaysian automotive industry. The authors focus on the implementation efforts in two dimensions, namely: recognition of social responsibility, and stakeholder identification and engagement. They propose a conceptual framework and suggest a methodology for model verification. Employing a case-study methodology, Moratis and Widjaja (2014) identify five main aspects that would affect the adoption of ISO 26000 standard, namely: external market forces, characteristics of the adopting organization, tangible as well as intangible attributes of the standard, and characteristics of the organization. 


\section{MInstitute ${ }^{\text {Mink }}$}

Business and Economic Research

ISSN 2162-4860

2016, Vol. 6, No. 2

A possible reason for such a limited pool of literature on ISO 26000 may attribute to the lack of appropriate measurement of CSR adoption based on the framework of the standard. In fact, very few studies concern scale development for CSR implementation. Singhapakdi, Vitell, Rallapalli and Kraft (1996) develop a measurement scale that focuses on the perceived role of ethics and CSR in organizational effectiveness. Carter and Jennings (2004) study the CSR aspect of the purchasing function (PSR) in a supply chain through a questionnaire survey. The authors develop a measure in PSR and then examine the drivers for PSR through a structural equation analysis. Garcia de los Salmoes, Herrero Crespo and Rodriguez del Bosque (2005) develop a scale that measures CSR from three dimensions, namely: economic responsibility, ethical-legal responsibility, and philanthropic responsibility. Making use of the scale, the authors explore the impact of CSR on consumer loyalty and service valuation. In recent studies, both Turker (2009) and Shafiq et al. (2014) develop CSR scales from multiple stakeholders' perspectives. Turker (2009) consolidates a number of existing scales into a four-dimensional scale that reflect CSR initiatives related to society, employees, customers, and government. Shafiq et al. (2014), on the other hand, make reference to Stakeholder Theory and focus on four types of stakeholders, namely: internal stakeholders (employees), suppliers, customers, and the community. They construct scales that measure socially responsible practices derived for these groups of stakeholders. Focusing on the consumer, Oberseder, Schlegelmilch, Murphy and Gruber (2014) and Alvarado-Herrera, Bigne, Aldas-Manzano and Curras-Perez (2015) separately develop scales to quantify the perceptions of this stakeholder group towards CSR. The former reveal different domains of CSR based on interviews with managers and consumers whilst the latter employ the concept of sustainability development and derive their scale into three dimensions, namely: economic, social and environmental.

It appears that there is no CSR scale specifically designed for ISO 26000. To bridge this gap in the literature, this paper aims to develop a scale that takes into consideration the ISO 26000 standard and that can be easily adapted and employed by practitioners. Table 1 lists the previous studies that had been reviewed above and states the positioning of this paper.

Table 1. List of related CSR literature and positioning of this paper

\begin{tabular}{|l|c|c|c|}
\hline & $\begin{array}{c}\text { ISO } \\
26000\end{array}$ & Quantitative & $\begin{array}{c}\text { Scale } \\
\text { Development }\end{array}$ \\
\hline $\begin{array}{l}\text { Castka \& Balzarova (2007; 2008); } \\
\text { Schwartz \& Tilling (2009); Habidin et al. (2012); }\end{array}$ & $\checkmark$ & & \\
$\begin{array}{l}\text { Fuzi et al. (2013); Hahn (2013); } \\
\text { Moratis \& Widjaja (2014) }\end{array}$ & $\checkmark$ & $\checkmark$ & \\
\hline Barnes \& Croker (2013) & & & \\
\hline $\begin{array}{l}\text { Singhapakdi et al. (1996); Carter \& Jennings (2004); Garcia de } \\
\text { los Salmons et al. (2005); } \\
\text { Turker (2009); Oberseder et al. (2014); } \\
\text { Shafiq et al. (2014); Alvarado-Herrera et al. (2015) }\end{array}$ & $\checkmark$ & $\checkmark$ \\
\hline This Paper & & & \\
\hline
\end{tabular}




\section{Methodology}

\subsection{Scale Design}

Following Churchill (1979) in conducing scale development, the scope of construct from the ISO 26000 guidance on social responsibility was first identified. Seven core subjects of social responsibility, namely: (a) organizational governance (OG), (b) human rights (HR), (c) labour practices (LP), (d) the environment (EN), (e) fair operating practices (FOP), (f) consumer issues (CI), and (g) community involvement and development (CID), with total 21 items were generated from the ISO 26000 guidelines. To have a preliminary test on the above constructs and underlying items, a practitioner who provides consultancy services for companies adopting ISO26000 was consulted.

\subsection{Data Collection and Sample Size}

The population of this study comprises organizations that are actively implementing CSR in Hong Kong. Two groups of organizations were therefore identified as the target respondents, namely: (1) awardees of the Caring Company/Organization Scheme and (2) publicly listed companies on the Main Board of Hong Kong Exchanges and Clearing Limited. The Caring Company/Organization Scheme was established in 2002 by the Hong Kong Council of Social Service, a leading non-government social service agency in Hong Kong. The scheme aims to cultivate and promote CSR commitment in both the public and private sectors in the form of a labelling system. Awardees of the scheme have to demonstrate outstanding performance in CSR with reference to a set of nomination criteria. On the other hand, listed companies are believed to be more obliged to adopt CSR principles and disclose their associated performance. Hence, both groups are deemed suitable candidates for this study.

In the survey, respondents were asked to evaluate the extent to which their organizations performed in the seven core subjects of CSR with respect to the proposed 21 measurement items. A five-point Likert scale, from $1=$ very low extent to $5=$ very high extent was used.

The data collection process took place during the period of April - September 2015. Self-administered questionnaires were sent by mail twice to the top management such as the chief executive officer or director of the target organizations. The initial mailing solicited 152 usable responses. A follow-up mailing was dispatched six weeks after the initial mailing and resulted in 134 additional usable responses. The final usable sample size was 286.

Presuming late respondents behave similarly as non-respondents, a non-response bias analysis was conducted by comparing the responses to the first mailing with those to the second mailing (Armstrong \& Overton, 1977). The results of the t-tests revealed no significant differences between the responses of two groups at the 5\% significance level. These suggest that non-response may not be a problem for this study.

Table 2 summarizes the demographic characteristics of the respondent organizations. $60 \%$ of the respondent organizations are large in size with over 100 employees. Slightly more than half $(53.8 \%)$ of them have operations outside Hong Kong. Nearly three quarters of them have been adopting CSR for five years or more. 
Table 2. Demographics of respondent organizations

\begin{tabular}{|l|l|r|r|}
\hline & & Frequency & $\%$ \\
\hline Total & & 286 & 100.0 \\
\hline \multirow{3}{*}{ By Organization Size } & SMEs (<=100 employees) & 111 & 38.8 \\
\cline { 2 - 4 } & Large (> 100 employees) & 175 & 61.2 \\
\hline \multirow{3}{*}{ By Operation Geography } & With operations outside HK & 154 & 53.8 \\
\cline { 2 - 4 } & Operate in HK only & 132 & 46.2 \\
\hline \multirow{3}{*}{ By Experience in CSR practices } & $<5$ years & 74 & 25.9 \\
\cline { 2 - 4 } & 5 - 10 years & 105 & 36.7 \\
\cline { 2 - 4 } & $>10$ years & 107 & 37.4 \\
\hline
\end{tabular}

\subsection{Scale Validation}

To assess the dimensionality of the proposed CSR scale, confirmatory factor analysis (CFA) was performed using AMOS software. The exploratory factor analysis (EFA) was skipped as the objective of this study is to validate the existing core subjects in ISO 26000 but not to explore new constructs. CFA, instead of EFA, is thus a more appropriate analysis method.

The initial fit of the full measurement model (i.e., with all the items included) suggested re-specification of the model is necessary. Specifically, the large modification indices of some relationships indicate that some items in various constructs had to be deleted. Based on the empirical evidence, the two constructs Consumer issue (CI) and Fair operating practices (FOP) should be combined into a single one (hereafter called Customer Protection - CP). A possible reason to such suggested combination may lie in the fact that these two constructs share similar concerns from the market / demand side and thus they were highly correlated. FOP focuses on purchase for commercial purposes (organization-to-organization) whilst CI mainly deals with matters related to purchase for private purposes (organization-to-individual). This is in line with ISO 26000's proposition that specific issues of these two core subjects could apply to either commercial customers or end consumers (Clause 6.7.1.1, ISO 26000 standard).

The modified measurement model (Figure 2 ) was verified to have good fit $(\chi 2 / \mathrm{df}=1.686<3$; $\mathrm{CFI}=0.974>0.95 ; \mathrm{RMSEA}=0.049<0.05 ; \mathrm{AGFI}=0.903>0.8 ;$ PCLOSE $=0.534>0.05)$ (Hu \& Bentler, 1999). The factor loadings of all items exceeded 0.68, which are well above the 0.40 threshold as suggested by the literature (Nunnally, 1978). To sum up, the CFA provided evidence for the factor structure of the proposed CSR scale. 


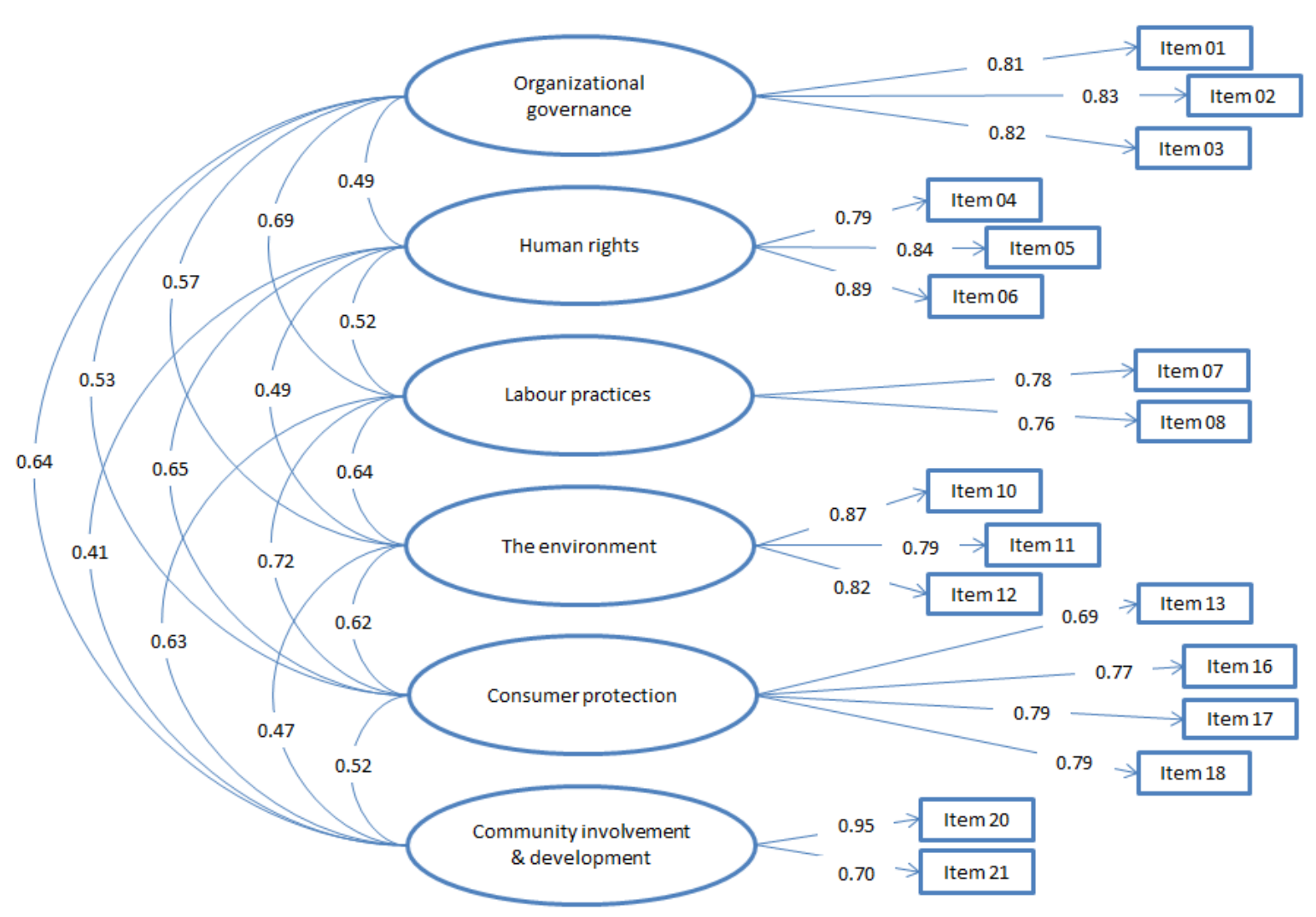

Figure 2. Results of CFA for the measurement model

To establish reliability as well as convergent and discriminant validity of the measurement model, the following metrics were computed with the Stats Tools Package developed by Gaskin (2012a): composite reliability (CR), average variance extracted (AVE), maximum shared variance (MSV), maximum reliability $\mathrm{H}$ statistics (MRH), and Pearson correlation coefficients. Tables 3 and 4 present the values of these metrics for individual constructs. The metrics were assessed by making reference to Hair, Black, Babin and Anderson (2010) (cited in Gaskin, 2012b) as well as Hancock and Mueller (2001) (cited in Gaskin, 2016) for the suggested thresholds as follows. Observed from Table 3, both the values of composite reliability (CR) and Cronbach alpha for all constructs exceeded 0.7 whereas the corrected item-total correlation (CITC) scores of individual items within each construct were well above the traditional cut-off value of 0.5 . The values of MRH were also over 0.8 for all constructs. Therefore, the constructs were believed to be reliable. The values of AVE for all constructs were greater than 0.5 , indicating no convergent validity issue for the constructs. Discriminant validity of the constructs were verified according to the below statistics. Firstly, for individual constructs, the AVE was greater than the respective MSV. Secondly, from Table 4, the square root of AVE of a construct was always greater than all inter-construct correlations related to that construct. To sum up, it was concluded that all factors demonstrate sufficient reliability and validity for further analysis. 
Table 3. Metrics for checking reliability and validity of constructs

\begin{tabular}{|c|c|c|c|c|c|c|c|c|}
\hline Construct & Item & & CITC & $\mathbf{C A}$ & $\mathbf{C R}$ & MRH & AVE & MSV \\
\hline \multirow[t]{3}{*}{$\begin{array}{l}\text { Organizational } \\
\text { Governance (OG) }\end{array}$} & 01 & $\begin{array}{l}\text { Development of CSR } \\
\text { strategies, objectives and } \\
\text { targets }\end{array}$ & .739 & \multirow[t]{3}{*}{.861} & \multirow[t]{3}{*}{.861} & \multirow[t]{3}{*}{.922} & \multirow[t]{3}{*}{.674} & \multirow[t]{3}{*}{.482} \\
\hline & 02 & $\begin{array}{l}\text { Leadership commitment } \\
\text { and accountability }\end{array}$ & .720 & & & & & \\
\hline & 03 & $\begin{array}{l}\text { Creation and nurturing of } \\
\text { an environment and } \\
\text { culture for CSR }\end{array}$ & .752 & & & & & \\
\hline \multirow[t]{3}{*}{ Human Rights (HR) } & 04 & $\begin{array}{l}\text { Free from discrimination } \\
\text { (e.g. race, colour, gender, } \\
\text { age, religion, etc.) }\end{array}$ & .722 & \multirow[t]{3}{*}{.873} & \multirow[t]{3}{*}{.877} & \multirow[t]{3}{*}{.951} & \multirow[t]{3}{*}{.704} & \multirow[t]{3}{*}{.416} \\
\hline & 05 & $\begin{array}{l}\text { Respect freedom of } \\
\text { opinion and expression }\end{array}$ & .760 & & & & & \\
\hline & 06 & $\begin{array}{l}\text { Respect right to life and } \\
\text { liberty }\end{array}$ & .792 & & & & & \\
\hline \multirow[t]{2}{*}{$\begin{array}{l}\text { Labour Practices } \\
\text { (LP) }\end{array}$} & 07 & $\begin{array}{l}\text { Human development and } \\
\text { training in the workplace }\end{array}$ & .589 & \multirow[t]{2}{*}{.738} & \multirow[t]{2}{*}{.741} & \multirow[t]{2}{*}{.957} & \multirow[t]{2}{*}{.589} & \multirow[t]{2}{*}{.520} \\
\hline & 08 & Health and safety at work & .589 & & & & & \\
\hline \multirow{3}{*}{$\begin{array}{l}\text { The Environment } \\
\text { (EN) }\end{array}$} & 10 & Prevention of pollution & .782 & \multirow[t]{3}{*}{.862} & \multirow[t]{3}{*}{.865} & \multirow[t]{3}{*}{.967} & \multirow[t]{3}{*}{.682} & \multirow[t]{3}{*}{.407} \\
\hline & 11 & $\begin{array}{l}\text { Sustainable use of } \\
\text { resources }\end{array}$ & .712 & & & & & \\
\hline & 12 & $\begin{array}{l}\text { Protection and restoration } \\
\text { of the natural } \\
\text { environment }\end{array}$ & .730 & & & & & \\
\hline \multirow{4}{*}{$\begin{array}{l}\text { Consumer Protection } \\
\text { (CP) }\end{array}$} & 13 & Anti-corruption & .644 & \multirow[t]{4}{*}{.861} & \multirow[t]{4}{*}{.846} & \multirow[t]{4}{*}{.850} & \multirow[t]{4}{*}{.579} & \multirow[t]{4}{*}{.520} \\
\hline & 16 & $\begin{array}{l}\text { Fair marketing, factual } \\
\text { and unbiased information }\end{array}$ & .669 & & & & & \\
\hline & 17 & $\begin{array}{l}\text { Protecting consumers' } \\
\text { health and safety }\end{array}$ & .708 & & & & & \\
\hline & 18 & $\begin{array}{l}\text { Consumer data protection } \\
\text { and privacy }\end{array}$ & .716 & & & & & \\
\hline \multirow{2}{*}{$\begin{array}{l}\text { Community } \\
\text { Involvement \& } \\
\text { Development (CID) }\end{array}$} & 20 & $\begin{array}{l}\text { Employment creation and } \\
\text { skills development }\end{array}$ & .666 & \multirow[t]{2}{*}{.800} & \multirow[t]{2}{*}{.819} & \multirow[t]{2}{*}{.975} & \multirow[t]{2}{*}{.698} & \multirow[t]{2}{*}{.411} \\
\hline & 21 & $\begin{array}{l}\text { Technology development } \\
\text { and access }\end{array}$ & .666 & & & & & \\
\hline
\end{tabular}

Note: CITIC: Corrected Item-Total Correlation; CA: Cronbach's alpha; CR: Composite reliability; MRH: Maximum reliability H statistics; AVE: Average variance extracted; MSV: Maximum shared variance. 
Table 4. Square root of Average Variance Extracted (AVE) of constructs and Pearson correlation coefficients between constructs

\begin{tabular}{|c|c|c|c|c|c|c|c|}
\hline \multirow{2}{*}{ Construct } & \multirow{2}{*}{ Square root of AVE } & \multicolumn{5}{|c|}{ Pearson correlation coefficients } \\
\cline { 4 - 8 } & & OG & HR & LP & EN & CP & CID \\
\hline OG & .821 & 1.000 & .485 & .694 & .568 & .533 & .641 \\
\hline HR & .839 & & 1.000 & .523 & .488 & .645 & .405 \\
\hline LP & .768 & & & 1.000 & .638 & .721 & .633 \\
\hline EN & .826 & & & & 1.000 & .619 & .472 \\
\hline CP & .761 & & & & & 1.000 & .523 \\
\hline CID & .836 & & & & & & 1.000 \\
\hline
\end{tabular}

Note: OG: Organizational Governance; HR: Human Rights; LP: Labour Practices; EN: The Environment; CP: Consumer Protection; CID: Community Involvement \& Development.

\section{Triangulation of the Measurement Scale: Industrial Evidence from In-depth Interviews}

To lend further credence to our measurement scale, interviews were conducted with senior executives of seven organizations (denoted by $C D C, S D L, H S H, S R H K, O P, F T H K$, and $L C H$ in the following text). These organizations comprise two listed companies, two private companies, and three non-profitable organizations, with operations covering Hong Kong, Macau, Mainland China, Asia, and the Middle East. Table 5 lists the profiles of these organizations.

Findings from the executive interviews, supplemented with various sources of public information like sustainability reports and annual reports, reflect that the approaches to CSR by these organizations are compliant with the proposed measurement scale (and in turn ISO 26000). A majority of the interviewee organizations have shown their emphasis on organizational governance (Construct OG). For instance, SRHK holds management meetings bi-annually to formulate CSR strategies. SDL has demonstrated leadership commitment and accountability through establishment of board-level CSR committees. Most of the interviewee organizations are endowed with clear corporate cultures and visions for CSR. In particular, both $C D C$ and $O P$ emphasize the essentiality to embed CSR into their daily operations.

A number of our interview organizations articulate their concerns about human rights (Construct HR). For example, FTHK actively promotes obligations to international bills of human rights within their sphere of influence in the business sector through fair trade. $C D C$ pursues the "Guide Dogs Welcome" policy, under which visually impaired customers and their guide dogs are welcome in the premises of its restaurants. $L C H$ adheres to the highest standard of human rights protection, equality, and non-discrimination in running its community centre. These practices conform to the proposed scale items in the human rights construct. 
Initiatives related to labour practices (Construct LP) are commonly observed in the CSR agendas of the interviewee organizations. Both $S R H K$ and $O P$ frequently arrange local and overseas training to equip their employees with better knowledge and skills. Others are concerned about the health and well-being of their employees. For example, SDL provides work-life balance courses. $C D C$ offers extra staff benefits such as housing allowances and paid paternity leave to male staff, the latter of which has only been put as statutory employee entitlement recently.

The interviewee organizations have been initiating a variety of measures to address environmental sustainability (Construct EN). SDL and SRHK implemented the ISO 14000 family of standards. SRHK also recommends their clients to adopt equipment with low pollution and high efficiency. $C D C$ established an Environmental Protection Centre in 2015 for centralized utensil cleaning to minimize its environmental impacts. The catering group also collaborates with the social enterprise Green Monday to introduce green diets. $O P$ designates the Environmental and Carbon Management Steering Committee to devise carbon reduction targets. HSH has Green Committee to oversee the green efforts of the company. The company pursues green purchasing policy for product and service selection. It also forms green teams to arouse environmental awareness within the company.

With respect to consumer protection (Construct $\mathrm{CP}$ ), $C D C$ employs stringent quality control and measures for its raw materials procurement to ensure food safety. Its recently built Central Food Processing Centre is operated under the ISO 22000 family of standards on food safety management. The catering group also works closely with its designated suppliers to monitor its supply chain in the form of supplier visits and assessment. It also procures sustainable seafood and fair trade certified beverage and snacks. In $H S H$, designated customer service officers are assigned to individual tenant customers for handling premise handover procedures and providing customer services. Apart from facilitating the sale and purchase of fair trade products, FTHK also monitors producers' eligible use of proceedings from fair trade. Furthermore, the organization actively promotes and educates the general public about the concept of fair trade.

Donations and volunteering services are common CSR practices among all interviewee organizations in terms of community involvement and development (Construct CID). In addition, the interviewee organizations have employed a variety of approaches to promote technology development and access in the territory. For instance, HSH has established two foundations to support innovative CSR projects in the fields of education, medical care, scientific research and disaster relief in Hong Kong and China. A number of interviewee organizations offer concessionary charges to the underprivileged people and non-governmental organizations (NGOs) for using their products or services. For example, $O P$ offers free admission for disabled people to its theme park. HSH, on the other hand, reserves $10 \%$ of the commercial space in one of its owned industrial buildings for renting to NGOs at a nominal rate. Many interviewee organizations (e.g. $C D C, S D L, H S H$ and $L C H$ ) also collaborate with other companies or NGOs for ingenious community services, some of which focus on skills development. For example, $L C H$ funds different organizations to provide training programs in computer usage and healthcare for elderly people. It also 
supports the establishment of a computer lab for the elderly in the neighborhood as well as an online platform to share healthcare information.

From the above, a close correspondence between the proposed measurement scale and real-world CSR practices by the interview organizations was observed.

Table 5. Profiles of the organizations interviewed

\begin{tabular}{|c|c|c|c|c|c|c|}
\hline & $\begin{array}{c}\text { Name of } \\
\text { Interviewee } \\
\text { Organization }\end{array}$ & $\begin{array}{l}\text { Operation } \\
\text { Nature }\end{array}$ & Industry / Scope & $\begin{array}{l}\text { Founded } \\
\text { Year }\end{array}$ & $\begin{array}{l}\text { Geographical } \\
\text { Span }\end{array}$ & $\begin{array}{c}\text { Title of } \\
\text { Interviewee }\end{array}$ \\
\hline 1 & $\begin{array}{l}\text { Cafe de Coral } \\
\text { Holdings } \\
\text { Limited } \\
(\mathrm{CDC})\end{array}$ & Listed company & $\begin{array}{l}\text { Restaurant, } \\
\text { catering and food } \\
\text { processing }\end{array}$ & 1968 & $\begin{array}{l}\text { Hong Kong } \\
\text { and China }\end{array}$ & $\begin{array}{l}\text { Honorary } \\
\text { Chairman }\end{array}$ \\
\hline 2 & $\begin{array}{l}\text { SOCAM } \\
\text { Development } \\
\text { Limited (SDL) }\end{array}$ & Listed company & $\begin{array}{l}\text { Property } \\
\text { development, } \\
\text { construction and } \\
\text { cement operation }\end{array}$ & 1971 & $\begin{array}{l}\text { Hong Kong, } \\
\text { Macau, and } \\
\text { China }\end{array}$ & $\begin{array}{l}\text { Deputy } \\
\text { General } \\
\text { Manager }\end{array}$ \\
\hline 3 & $\begin{array}{l}\text { Hip Shing } \\
\text { Hong } \\
\text { (Holdings) } \\
\text { Company } \\
\text { Limited (HSH) }\end{array}$ & Private company & $\begin{array}{l}\text { Property } \\
\text { development }\end{array}$ & 1948 & Hong Kong & $\begin{array}{l}\text { Assistant PR } \\
\text { Manager }\end{array}$ \\
\hline 4 & $\begin{array}{l}\text { Shinryo (Hong } \\
\text { Kong) Limited } \\
\text { (SRHK) }\end{array}$ & $\begin{array}{l}\text { Private company } \\
\text { under a Japanese } \\
\text { parent company }\end{array}$ & $\begin{array}{l}\text { Electrical and } \\
\text { mechanical } \\
\text { engineering }\end{array}$ & 1982 & $\begin{array}{l}\text { Asia and } \\
\text { Middle East }\end{array}$ & $\begin{array}{l}\text { Assistant } \\
\text { General } \\
\text { Manager, } \\
\text { HR and } \\
\text { Admin. }\end{array}$ \\
\hline 5 & $\begin{array}{l}\text { Ocean Park } \\
\text { Corporation } \\
\text { (OP) }\end{array}$ & $\begin{array}{l}\text { Non-profitable } \\
\text { organization }\end{array}$ & $\begin{array}{l}\text { Theme park } \\
\text { (Entertainment, } \\
\text { education and } \\
\text { conservation) }\end{array}$ & 1977 & Hong Kong & $\begin{array}{l}\text { Deputy CE } \\
\text { and CFO }\end{array}$ \\
\hline 6 & $\begin{array}{l}\text { Fair Trade } \\
\text { Hong Kong } \\
\text { Foundation } \\
(\text { FTHK) }\end{array}$ & $\begin{array}{l}\text { Non-profitable } \\
\text { organization }\end{array}$ & $\begin{array}{l}\text { Fair trade } \\
\text { promotion and } \\
\text { education }\end{array}$ & 2008 & $\begin{array}{l}\text { Hong Kong, } \\
\text { Macau, and } \\
\text { China }\end{array}$ & $\begin{array}{l}\text { Executive } \\
\text { Secretary }\end{array}$ \\
\hline 7 & $\begin{array}{l}\mathrm{LCH} \\
\text { Charitable } \\
\text { Foundation } \\
(\mathrm{LCH})\end{array}$ & $\begin{array}{l}\text { Non-profitable } \\
\text { organization } \\
\text { supported by a } \\
\text { private parent } \\
\text { company }\end{array}$ & Elderly services & 2009 & Hong Kong & Chairman \\
\hline
\end{tabular}

\section{Discussion}

With reference to the factor structure of the proposed measurement scale, findings from the executive interviews were further analyzed to provide insights regarding recent CSR adoption in Hong Kong as follows. 
Amongst the various constructs, it appears that interviewee organizations are most involved in CSR practices that concern the environment, labour practices, as well as community involvement and development (Constructs EN, LP and CID, respectively). For example, SDL and $S R H K$ operate under ISO 14001 certification. In fact, there is a high level of awareness and efforts devoted to environmental concern by organizations throughout the world. A possible reason of this phenomenon may lie on the increasing public awareness of the various environmental problems and issues (such as global warming and climate change) and the subsequent impact on consumer behavior (Mainieri, Barnett, Valdero, Unipan \& Oskamp, 1997; Grimmer \& Bingham, 2013). Implementation and certification of environmental management systems can demonstrate an organization's commitment to environmental protection and make the organization more competitive (Rondinelli \& Vastag, 2000). Besides, existence of quantifiable goals for most environmental initiatives may also make extensive environmental efforts feasible. Organizations can systematically monitor and evaluate the effectiveness of those environmental initiatives based on quantitative performance indicators. Furthermore, green initiatives undertaken by organizations are usually related to improvements in the environmental consequences of their activities (e.g. reduction in energy and water consumption, increased use of recycled materials, etc.). They can bring about cost reduction and operations efficiency improvement (Morrow \& Rondinelli, 2002), which provides a strong incentive for organizations' undertaking of those environmental initiatives.

There is a high level of labour practices (Construct LP) in Hong Kong. On the one hand, the stringent legal system safeguards a relatively high level of labour right protection in the city. Global labour issues like sweatshop labour and child labour virtually does not exist here. On the other hand, a majority of organizations view provision of employee benefits and training not only as their social responsibility but also as a competitive advantage to attract and retain competent employees. In fact, a myriad of information regarding practices on employee welfare and skills development can be found from different public sources like corporate annual/sustainability reports and websites for many organizations in Hong Kong. Nevertheless, issues like standard working hours (SWHC website, n.d.) and the offset mechanism of mandatory provident fund (Tsang, 6 December 2015) are some of the recent labour issues that arouse controversy in the territory.

With respect to community involvement and development (Construct CID), financial contributions and charitable activities are commonly practiced among all interviewee organizations. Voluntary in nature, philanthropy is a category of CSR that is highly desired by the society (Carroll, 1991). These activities are normally detached from the main operations of the organizations and do not involve any structural change of the business processes (e.g. when compared with some of the environmental practices). They can be executed fairly readily given the availability of the financial and manpower resources. Financial assistance is also a common form for organizations to contribute in skills and technology development in local communities.

By contrast, issues related to human rights (Construct HR) appears to be less communicated during the executive interviewees. Hong Kong being a place with a relatively high regard for human rights, organizations here inherently observe human rights in general. The 
establishment of the statutory body, The Equal Opportunities Commission, in 1996 and the recent enactment of a series of Discrimination Ordinances further reinforce the legal responsibilities of the organizations in the city (EOC website, n.d.). Individually, organizations here tend to address to the human rights aspect of CSR by paying attention to the daily needs of the minority groups that are related to their operations (e.g. $C D C$ 's "Guide Dogs Welcome" Policy).

While our empirical findings suggest combining the original two constructs - consumer issues and fair operating practices into one construct (named as Consumer Protection, CP), the findings from our interviewee organizations are also consistent with this. Consumer protection refers to the protection of consumer rights such as their health, safety, and privacy as well as maintaining a healthy and fair market for consumption. Interviewee organizations attach great prominence to sustaining a healthy market environment in the presence of various legal obligations in Hong Kong such as the Anti-Corruption Laws, Personal Data Privacy Ordinance, and the recently in-forced Competition Law. Some organizations (e.g. $C D C$ ) are well aware of the importance of supplier partnership and engage their suppliers to ensure product / service quality (Homburg, Stierl, \& Bornemann, 2013). The concept of fair trade is also practiced and promoted by a number of organizations (e.g. CDC, FTHK) in the city.

Observed from the interviews, the private sector in Hong Kong appears to take a strategic approach to CSR (McWilliams \& Siegel, 2011) by leveraging their business operations on their CSR efforts. For instance, $C D C$, as a listed company in catering and food processing, highlights food quality and food waste management in its CSR initiatives. $H S H$, on the other hand, makes use of its role as a private property developer to offer space to NGOs at a nominal rent. Apart from self-initiated projects, there also seems to be a tendency for interviewee companies in the private sector to collaborate with and/or sponsor NGOs in various community projects. Usually focused on single socio-environmental issues, NGOs are equipped with the expertise and knowledge in the respective domains. Partnership between private sector and NGOs can bring synergy and help optimize the operational efficiency and effectiveness of the CSR campaigns.

Organizational governance (Construct OG) is regarded by ISO 26000 as the most important element that endows an organization with socially responsible behavior (Clause 6.2.1.2, ISO 26000 standard). Accordingly, interviewee organizations have demonstrated their emphasis on this key area in their CSR approach, with leadership commitment and organization culture as some of the key features highlighted. It is widely agreed that top management commitment and corporate culture are the essential resources that define the capabilities of an organization to formulate and direct its long-term strategy (Grant, 1991). Corporate culture can also affect an organization's orientation towards social responsibility (Galbreath, 2010). There are studies suggesting the interrelationships and the possible synergies between organizational governance and CSR (Jamali, Safieddine, \& Rabbath, 2008). It is therefore desirable for organizations to instill the concept of CSR into their daily operations and to foster a socially responsible culture within the sphere of their influence. 


\section{Conclusion, Limitation and Future Directions}

This study operationalizes and validates a scale to measure an organization's extent of CSR adoption in the context of ISO 26000 with a mixed methodological approach. Quantitatively, reliability, convergent, and discriminant validity of the scale had been established with respect to the data collated from a questionnaire survey. Qualitatively, the scale was triangulated based on interviews with a variety of organizations regarding their real-world practices.

ISO 26000 is one of the prevalent international standards that guide organizations' approach to CSR with a multi-stakeholder perspective. Organizations pursue CSR initiatives to fulfill the expectations and requirements of different stakeholders and they look for concrete measurement for performance evaluation. Managerially, this study contributes to the industry by developing an empirically validated scale which serves as a useful tool for practitioners to quantify and assess their CSR performance. The proposed measurement scale was developed under the context of ISO 26000. It is especially relevant for organizations that follow the standard to plan and execute their CSR initiatives. As demonstrated by our discussion above, the factor structure of the proposed scale can help an organization to identify key CSR areas for improvement. Academically, our measurement scale lays a foundation to future studies in CSR and particularly in ISO 26000 since constructs are a prerequisite for hypotheses and theory development.

There are limitations to this study. First, the data for the current study were solicited in the form of a mail questionnaire survey. Since the study relies on the self-reporting perceptions of the respondents, social desirability bias (Fisher, 1993) could exist. In particular, as discussed in the empirical literature on social responsibility (e.g., Godos-Diez, Fernandez-Gago, \& Martinez-Campillo, 2011), the essence of the topic of the current study may induce some respondents to overvalue the degree of CSR adoption in their organizations. Yet, effort had been made to minimize the bias by both the quantitative and qualitative triangulation. Another possible limitation lies on the confined sample frame. This study reflects the practices of only a sample of organizations in Hong Kong, a developed cosmopolitan city with a relatively well-established legal system and high living standards. Many fundamental CSR concerns are well-practiced and treated as norms here. The city also embraces eastern culture and ethics that may influence the perceptions and in turn the CSR practice of local companies and organizations. Future studies are encouraged to test with diverse samples from countries at different stages of development and with different cultures for further generalization of the scale.

There is numerous potential for future research in CSR with the use of the proposed scale. It would be fruitful to explore the antecedents and impacts of CSR adoption. Besides, it would be interesting to examine the influence of different stakeholders on driving CSR engagement of organizations. Another future research direction would be to explore and compare the extent of CSR amongst organizations of different natures. 


\section{Acknowledgement}

The authors would like to express their sincere gratitude to the senior executives with whom they had conducted interviews for their time and valuable input. This research was fully supported by a grant from the Research Grants Council of the Hong Kong Special Administrative Region, China (UGC/IDS12/14).

\section{References}

Ackermann, F., \& Eden, C. (2011). Strategic Management of Stakeholders: Theory and Practice. Long Range Planning, 44, 179-196. http://dx.doi.org/10.1016/j.lrp.2010.08.001

Alvarado-Herrera, A., Bigne, E., Aldas-Manzano, J., \& Curras-Perez, R. (2015). A Scale for Measuring Consumer Perceptions of Corporate Social Responsibility Following the Sustainable Development Paradigm. Journal of Business Ethics. http://dx.doi.org/10.1007/s10551-015-2654-9

Armstrong, J. S., \& Overton, T. S. (1977). Estimating Nonresponse Bias in Mail Surveys. Journal of Marketing Research, 14, 396-402. http://dx.doi.org/10.2307/3150783

Barnes, L. R., \& Croker, N. (2013). The Relevance of the ISO26000 Social Responsibility Issues to the Hong Kong Construction Industry. Australasian Journal of Construction Economics and Building, 13(3), 37-50. http://dx.doi.org/10.5130/ajceb.v13i3.3280

Carroll, A. B. (1991). The Pyramid of Corporate Social Responsibility: Toward the Moral Management of Organizational Stakeholders. Business Horizons, 34(4), 39-48. http://dx.doi.org/10.1016/0007-6813(91)90005-G

Carter, C. R., \& Jennings, M. M. (2004). The role of purchasing in corporate social responsibility: A structural equation analysis. Journal of Business Logistics, 25(1), 145-186. http://dx.doi.org/10.1002/j.2158-1592.2004.tb00173.x

Castka, P., \& Balzarova, M. A. (2007). A critical look on quality through CSR lenses: Key challenges stemming from the devlopment of ISO26000. International Journal of Quality \& Reliability Management, 24(7), 738-752. http://dx.doi.org/10.1108/02656710710774700

Castka, P., \& Balzarova, M. A. (2008). ISO 26000 and supply chains - On the diffusion of the social responsibility standard. International Journal of Production Economics, 111, 274-286. http://dx.doi.org/10.1016/j.ijpe.2006.10.017

Churchill, G. A. (1979). A Paradigm for Developing Better Measures of Marketing Constructs. Journal of Marketing Research, 16, 64-73. http://dx.doi.org/10.2307/3150876

De Brucker, K., Macharis, C., \& Verbeke, A. (2013). Multi-criteria analysis and the resolution of sustainable development dilemmas: A stakeholder management approach. European Journal of Operational Research, 224, 122-131. http://dx.doi.org/10.1016/j.ejor.2012.02.021

Donaldson, T., \& Preston, L. E. (1995). The Stakeholder Theory of the Corporation: Concepts, Evidence, and Implications. Academy of Management Review, 20(1), 65-91. 
EOC website. (n.d.). What is EOC. [Online]. Retrieved from: http://www.eoc.org.hk/eoc/graphicsfolder/showcontent.aspx?content=our\%20work-what $\% 20$ is $\% 20 \mathrm{eoc}$

Fisher, R. J. (1993). Social Desirability Bias and the Validity of Indirect Questioning. Journal of Consumer Research, 20, 303-315. http://dx.doi.org/10.1086/209351

Freeman, R. E. (1984). Strategic management: A stakeholder approach. Boston: Pitman.

Freeman, R. E. (1994). The Politics of Stakeholder Theory: Some Future Directions. Business Ethics Quarterly, 4(4), 409-422. http://dx.doi.org/10.2307/3857340

Freeman, R. E., \& Reed, D. L. (1983). Stockholders and Stakeholders: A New Perspective on Corporate Governance. California Management Review, 25(3), 88-106. http://dx.doi.org/10.2307/41165018

Frow, P., \& Payne, A. (2011). A stakeholder perspective of the value proposition concept. $\begin{array}{llll}\text { European Journal } & \text { 223-240. }\end{array}$ http://dx.doi.org/10.1108/03090561111095676

Fuzi, N. M., Habidin, N. F., Desa, A., Zamri, F., \& Hibadullah, S. (2013). Corporate Social Responsibility Practices, ISO 26000 Efforts and CSR Performance in Malaysian Automotive Industry. International Journal of Managerial and Financial Accounting, 5(3), 277-293. http://dx.doi.org/10.1504/IJMFA.2013.058550

Galbreath, J. (2010). Drivers of Corporate Social Responsibility: The Role of Formal Strategic Planning and Firm Culture. British Journal of Management, 21(2), 511-525. http://dx.doi.org/ 10.1111/j.1467-8551.2009.00633.x

Garcia de los Salmoes, M., Herrero Crespo, A., \& Rodriguez del Bosque, I. (2005). Influence of Corporate Social Responsibility on Loyalty and Valuation of Services. Journal of Business Ethics, 61(4), 369-385. http://dx.doi.org/10.1007/s10551-005-5841-2

Gaskin, J. (2012a). Validity Master. Stats Tools Package. [Online]. Retrieved from: http://statwiki.kolobkreations.com

Gaskin, J. (2012b). Confirmatory Factor Analysis. [Online]. Retrieved from: http://statwiki.kolobkreations.com

Gaskin, J. (2016, May 3). SEM Series (2016) 5c. CFA Validity correction [Video file]. Retrieved from: https://www.youtube.com/watch?v=8Sumk785Fmc\&feature=youtu.be

Godos-Diez, J.-L., Fernandez-Gago, R., \& Martinez-Campillo, A. (2011). How important Are CEOs to CSR Practices? An Analysis of the Mediating Effect of the Perceived Role of Ethics and Social Responsibility. Journal of Business Ethics, 98, 531-548. http://dx.doi.org/10.1007/s10551-010-0609-8

Grant, R. M. (1991). The Resource-Based Theory of Competitive Advantage: Implications for Strategic Formulation. California Management Review, 33(3), 114-135. http://dx.doi.org/10.2307/41166664 
GRI. (2013). G4 Sustainability Reporting Guidelines. [Online]. Retrieved from: https://www.globalreporting.org/standards/g4/Pages/default.aspx

Grimmer, M., \& Bingham, T. (2013). Company environmental performance and consumer purchase intentions. Journal of Business Research, 66(10), 1945-1953. http://dx.doi.org/10.1016/j.jbusres.2013.02.017

Habidin, N. F., Fuzi, N. M., Desa, A., Hibadullah, S. N., \& Zamri, F. (2012). Corporate Social Responsibility Practices (CSRP) and ISO 26000 Performance Efforts in Malaysian Automotive Industry. International Journal of Economics, Finance and Management, 1(1), $1-7$.

Hahn, R. (2013). ISO 26000 and the Standardization of Strategic Management Processes for Sustainability and Corporate Social Responsibility. Business Strategy and the Environment, 22, 442-455. http://dx.doi.org/10.1002/bse.1751

Hair, J. F., Black, W. C., Babin, B. J., \& Anderson, R. E. (2010). Multivariate Data Analysis (7th ed.). Upper Saddle River, NJ: Prentice-Hall.

Hancock, G. R., \& Mueller, R. O. (2001). Rethinking construct reliability within latent variable systems, in R. Cudeck, S. du Toit, \& D. Sorbom (Ed.), Structural Equation Modeling: Present and Future: A Festschrift in honor of Karl Joreskog (pp. 195-214). Lincolnwood: Scientific Software International, Inc.

Homburg, C., Stierl, M., \& Bornemann, T. (2013). Corporate Social Responsibility in Business-to-Business Markets: How Organizational Customers Account for Supplier Corporate Social Responsibility Engagement. Journal of Marketing, 77(6), 54-72. http://dx.doi.org/10.1509/jm.12.0089

Hu, L.-t., \& Bentler, P. M. (1999). Cutoff criteria for fit indexes in covariance structure analysis: Conventional criteria versus new alternatives. Structural Equation Modeling: A Multidisciplinary Journal, 6(1), 1-55. http://dx.doi.org/10.1080/10705519909540118

ISO. (n.d.). Social responsibility: 7 core subjects. [Online]. Retrieved from: http://www.iso.org/iso/sr_7_core_subjects.pdf

ISO. (2010). ISO 26000:2010 - Guidance on social responsibility. Switzerland: International Organization for Standardization.

Jamali, D., Safieddine, A. M., \& Rabbath, M. (2008). Corporate Governance and Corporate Social Responsibility Synergies and Interrelationships. Corporate Governance: An International Review, 16(5), 443-459. http://dx.doi.org/10.1111/j.1467-8683.2008.00702.x

Jones, T. M., Wicks, A. C., \& Freeman, R. E. (2002). Stakeholder Theory: The State of the Art. In N. E. Bowie (Ed.), The Blackwell Guide to Business Ethics (pp. 19-37). Malden, Massachusetts: Blackwell.

Laplume, A. O., Sonpar, K., \& Litz, R. A. (2008). Stakeholder Theory: Reviewing a Theory That Moves Us. Journal of Management, 34(6), 1152-1189. 
http://dx.doi.org/10.1177/0149206308324322

Lazarte, M. (10 January 2013). ISO 26000 - International forum revisits the road travelled. [Press Release]. Retrieved from http://www.iso.org/iso/news.htm?refid=Ref1691

Mainieri, T., Barnett, E. G., Valdero, T. R., Unipan, J. B., \& Oskamp, S. (1997). Green Buying: The Influence of Environmental Concern on Consumer Behavior. The Journal of Social Psychology, 137(2), 189-204. http://dx.doi.org/10.1080/00224549709595430

Manetti, G. (2011). The Quality of Stakeholder Engagement in Sustainability Reporting: Empirical Evidence and Critical Points. Corporate Social Responsibility and Environment Management, 18, 110-122. http://dx.doi.org/10.1002/csr.255

Moratis, L., \& Widjaja, A. T. (2014). Determinants of CSR standards adoption: exploring the case of ISO 26000 and the CSR performance ladder in The Netherlands. Social Responsibility Journal, 10(3), 516-536. http://dx.doi.org/10.1108/SRJ-01-2013-0005

Morrow, D., \& Rondinelli, D. (2002). Adopting Corporate Environmental Management Systems: Motivations and Results of ISO 14001 and EMAS Certification. European Management Journal, 20(2), 159-171. http://dx.doi.org/10.1016/S0263-2373(02)00026-9

McWilliams, A., \& Siegel, D. S. (2011). Creating and Capturing Value: Strategic Corporate Social Responsibility, Resource-Based Theory, and Sustainable Competitive Advantage. Journal of Management, 37(5), 1480-1495. http://dx.doi.org/10.1177/0149206310385696

Nunnally, J. C. (1978). Psychometric Theory (2nd ed.). New York: McGraw-Hill.

Oberseder, M., Schlegelmilch, B. B., Murphy, P. E., \& Gruber, V. (2014). Consumers' Perceptions of Corporate Social Responsibility: Scale Development and Validation. Journal of Business Ethics, 124(1), 101-115. http://dx.doi.org/10.1007/s10551-013-1787-y

Parmar, B. L., Freeman, R. E., Harrison, J. S., Wicks, A. C., Purnell, L., \& de Colle, S. (2010). Stakeholder Theory: The State of the Art. The Academy of Management Annals, 4(1), 403-445. http://dx.doi.org/10.1080/19416520.2010.495581

Post, J. E., Preston, L. E., \& Sachs, S. (2002). Managing the Extended Enterprise: The New Stakeholder View. California Management Review, 45(1), 6-28. http://dx.doi.org/10.2307/41166151

Rondinelli, D. A., \& Vastag, G. (2000). Panacea common sense or just a label? The value of ISO 14001 environmental management systems. European Management Journal, 18(5), 499-510. http://dx.doi.org/10.1016/S0263-2373(00)00039-6

Schwartz, B., \& Tilling, K. (2009). 'ISO-lating' Corporate Social responsibility in the Organizational Context: A Dissenting Interpretation of ISO 26000. Corporate Social Responsibility and Environment Management, 16, 298-299. http://dx.doi.org/10.1002/csr.211

Shafiq, A., Klassen, R. D., \& Johnson, P. F. (2014). Socially Responsible Practices: An Exploratory Study on Scale Development using Stakeholder Theory. Decision Sciences, 45(4), 683-716. http://dx.doi.org/10.1111/deci.12085 


\section{Macrothink}

Business and Economic Research

ISSN 2162-4860 2016, Vol. 6, No. 2

Singhapakdi, A., Vitell, S. J., Rallapalli, K. C., \& Kraft, K. L. (1996). The perceived role of ethics and social responsibility: A scale development. Journal of Business Ethics, 15, 1131-1140. http://dx.doi.org/10.1007/BF00412812

SWHC website. (n.d.). Standard Working Hours Committee - Welcome Message. [Online]. Retrieved from: http://www.swhc.org.hk/en/welcome_message/index.html

Tsang, E. (6 December 2015). Offset mechanism to feature in Hong Kong MPF consultation. [Online]. Retrieved from: http://www.scmp.com/news/hong-kong/politics/article/1887380/offset-mechanism-feature-ho ng-kong-mpf-consultation

Turker, D. (2009). Measuring Corporate Social Responsibility: A Scale Development Study. Journal of Business Ethics, 85, 411-427. http://dx.doi.org/10.1007/s10551-008-9780-6

United Nation Global Compact. (2014). Guide to Corporate Sustainability: Shaping a Sustainable Future. [Online]. Retrieved from: https://www.unglobalcompact.org/docs/publications/UN_Global_Compact_Guide_to_Corpor ate_Sustainability.pdf

\section{Copyright Disclaimer}

Copyright for this article is retained by the author(s), with first publication rights granted to the journal.

This is an open-access article distributed under the terms and conditions of the Creative Commons Attribution license (http://creativecommons.org/licenses/by/3.0/). 